\title{
Desain Sistem Otomasi Bilik Disinfektan Berbasis Arduino Uno
}

\author{
Sri Muntiah Andriani ${ }^{1}$ \\ ${ }^{1}$ Program Studi Teknik Listrik Politeknik Kotabaru \\ Muntai1995.ma@gmail.com
}

\begin{abstract}
ABSTRAK - Maraknya virus COVID-19 yang sudah menelan korban jiwa, dan manusia harus di isolasi baik yang sudah terjangkit virus maupun yang belum terjangkit. Dari permasalahan tersebut diperlukan sebuah sistem sterilisasi untuk manusia agar tidak mudah terkena virus tersebut. Terutama untuk orang-orang yang tetap harus bekerja di luar rumah seperti para ojek online, tenaga medis dan lain-lain. Sistem sterilisasi yang akan dibuat ini berupa bilik yang disemprotkan cairan disinfektan ke dalamnya setelah ada orang yang masuk untuk melindungi mereka dari serangan virus mematikan tersebut. Bilik disinfektan tersebut menggunakan sistem otomatis yang akan menyemprotkan cairan disinfektan setelah mendeteksi keberadaan orang di dalam bilik. Sistem tersebut menggunakan sensor PIR (Passive Infrared) yang dapat mendeteksi pergerakan manusia yang ada di dalamnya. Arduino Uno digunakan sebagai basis pemrograman otomatis untuk menjalankan pompa yang akan memompa cairan disinfektan ke dalam bilik yang juga tersambung dengan modul Relay untuk dapat menjalankan pompa tersebut.
\end{abstract}

Bilik disinfektan ini menggunakan sistem otomasi dengan kebutuhan cairan disinfektan setiap orang sekitar $24 \mathrm{~mL}$. Volume tangki penampung yang digunakan sebesar 20 liter dan bisa menyemprotkan orang sekitar 800 orang. Hal ini cukup efektif untuk menekan penyebaran COVID-19 jika dilihat dari kebutuhan cairan disinfektan untuk setiap orangnya. Pendeteksian sensor PIR di dalam bilik disinfektan juga sangat efektif, dilihat dari respon sensor PIR yang diperoleh sejauh $100 \mathrm{~m}$. Karena jarak terjauh dari sensor PIR dalam bilik tersebut adalah $100 \mathrm{~m}$, sehingga dapat disimpulkan bahwa pendeteksian sensor PIR sangat efektif dan juga responsif.

Kata Kunci : Bilik Disinfektan, COVID - 19, PIR, Arduino, dan Relay

\section{PENDAHULUAN}

Bilik disinfektan merupakan bilik yang digunakan untuk membersihkan orang dengan cairan disinfektan yang disemprotkan ke tubuh manusia agar dapat terhindar dari segala macam virus atau bakteri. Pengadaan bilik disinfektan ini sangat penting untuk wilayah - wilayah tertentu khusunya yang sudah berada pada zona merah (zona yang memiliki infeksi virus yang tinggi). Bilik disinfektan ini untuk membantu wilayah zona merah menekan bertambahnya orang yang terinfeksi virus corona tersebut. Di beberapa daerah sudah tersedia fasilitas untuk menekan penyebaran bakteri atau virus berbahaya khususnya virus corona yang sedang mewabah saat sekarang ini.Sistem bilik disinfektan ini memiliki sistem yang otomatis dengan menggunakan sensor PIR (Passive Infrared)untuk mendeteksi objek yang dilewati agar bisa menjalankan pompa untuk menyemprotkan cairan disinfektan yang ada dalam bilik tersebut.

Pembuatan bilik disinfektan ini menggunakan komponen elektronik utama yaitu sensor PIR (passive infrared) yang digunakan untuk mendeteksi pergerakan orang yang masuk ke dalam bilik disinfektan, arduino uno yang berfungsi untuk memprogram sistem menjadi otomatis yang tersambung ke sensor dan pompa. Komponen elektronik bantu juga digunakan seperti Relay yang digunakan sebagai protektor dan 
juga dapat sebagai switch ON/OFF untuk rangkaian bilik disinfektan, pompa DC (direct current) untuk memompa cairan disinfektan ke dalam bilik, selang pneumatik dan nozel untuk mengalirkan dan menyemprotkan cairan disinfektan ke dala bilik. Bilik disinfektan ini diharapkan bisa menjadi alternatif untuk membantu dalam memerangi virus COVID-19 yang sedang marak dan juga untuk mengurangi kemungkinan orang lain terkena jenis virus tersebut.

\section{METODE PENELITIAN}

\subsection{Diagram Aliran Program}

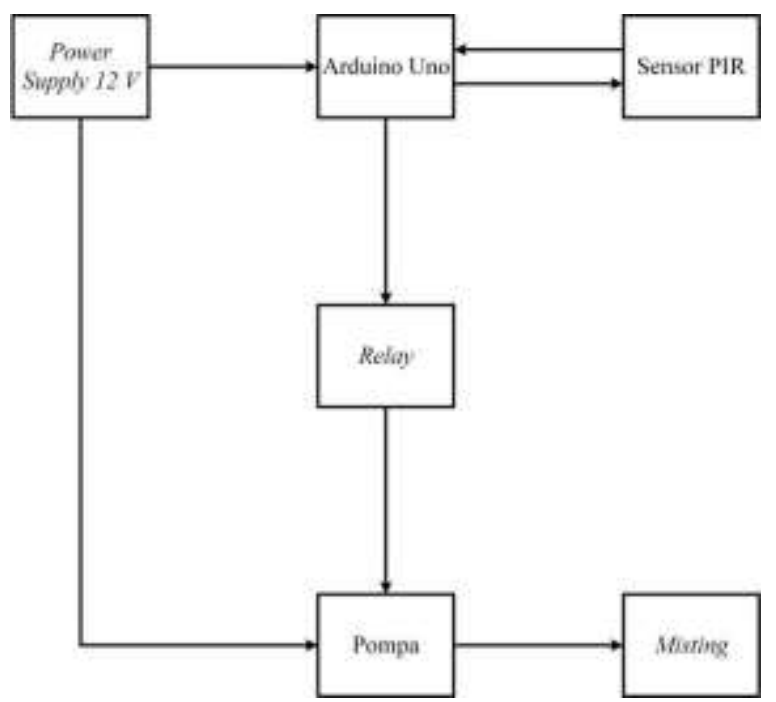

Gambar 1. Diagram alir program otomasi

Untuk proses pengambilan datanya :

1. Data Primer

Pengambilan data dilakukan dengan mengaplikasikan alat secara langsung ke manusia yang menggunakan cairan disinfektan yang lebih aman untuk manusia atau data yang diperoleh dari pengamatan secara langsung.

2. Data Sekunder

Data sekunder diperoleh dari beberapa referensi seperti jurnal penelitian mengenai COVID-19, berita online dan sosial mediamengenai perkembangan dan penanganan COVID-19 yang ada di beberapa wilayah di Indonesia.

\subsection{Desain Bilik Disinfektan}

Bilik disinfektan memiliki dimensi tinggi $200 \mathrm{~cm}$, lebar $100 \mathrm{~cm}$ dan ketebalan baja ringan yang digunakan $1 \mathrm{~cm}$ seperti yang terlihat pada gambar 2, gambar 3. dan Gambar 4. Luas bilik disinfektan yang dirancang yaitu $20.000 \mathrm{~cm}^{2}$ atau $2 \mathrm{~m}^{2}$. Bilik disinfektan ini memiliki pompa dan kotak tempat kelistrikan untuk mengalirkan cairan disinfektan yang terpasang di bagian kanan bilik seperti yang terlihat pada Gambar 4 . bilik tersebut memiliki kapasitas untuk 1 orang.

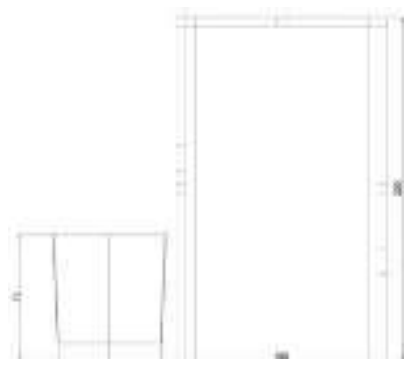

(a)

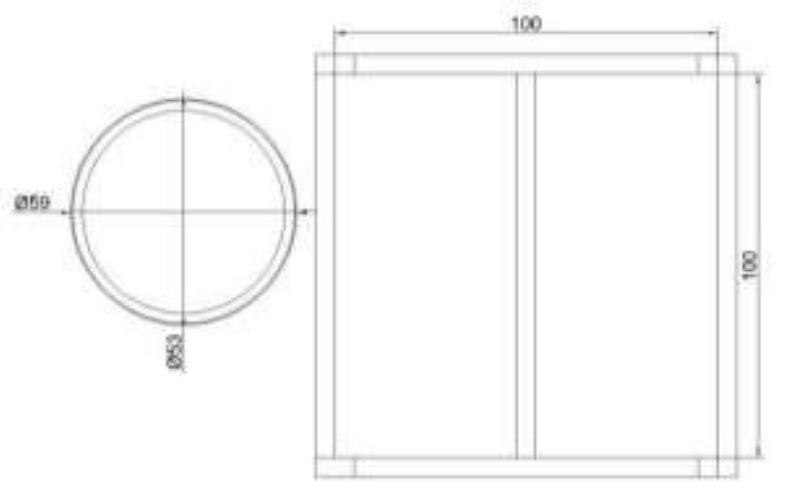

(b)

Gambar 2. Desain Bilik Disinfektan (a) tampak depan (b) tampak atas

Tangki penampung memiliki tinggi $376 \mathrm{~mm}$, diameter atas $320 \mathrm{~mm}$ dan diameter bawah $262 \mathrm{~mm}$. Volume tangki penampung cairan $20 \mathrm{~L}$.

2.3 Rangkaian Alat dan Cara Kerja Cara kerja bilik disinfektan: 
a. Orang masuk ke dalam bilik disinfektan, kemudian PIR yang sudah dirangkai mendeteksi keberadaan orang di dalam bilik.

b. Setelah PIR mendeteksi keberadaan orang dalam bilik tersebut, kemudian sensor akan mengirimkan sinyal berupa data ke Arduino Uno yang sudah di masukkan program untuk membaca data dari sensor PIR.

c. Arduino Uno yang sudah membaca data dari sensor PIR akan memberikan instruksi berupa sinyal ke Relay untuk menyalakan pompa yang sudah tersambung ke cairan disinfektan dan nozel yang ada dalam bilik.

d. Nozel kemudin menyemprotkan cairan disinfektan yang di pompa tadi ke suluruh bagian dalam ruangan bilik tersebut.

\section{DATA HASIL PENELITIAN DAN PEMBAHASAN}

Pengujian dilakukan untuk melihat seberapa efektif sistem otomasi yang dibuat dengan menggunakan air dan juga untuk memastikan sistem misting yang dipasang tidak mengalami kendala seperti ada penyumbatan dan lain sebagainya. Pengujian ini juga untuk memastikan keamanan saat diterapkan kepada orang dan juga seberapa banyak cairan disinfektan yang dibutuhkan untuk menyemprot 1 orang. Percoobaan dilakukan terhadap sensor PIR yang digunakan, seberapa efektif sensor tersebut bekerja pada jarak yang telah ditentukan sesuai yang disajikan pada Tabel 1. berikut:

Tabel 1. Hasil pengujian efektivitas sensor PIR berdasarkan jarak

\begin{tabular}{clcc}
\hline No. & Percobaan & Jarak & Hasil \\
\hline 1 & Pertama & $20 \mathrm{~cm}$ & Respon sangat cepat $(<1 \mathrm{~s})$ \\
\hline 2 & Kedua & $40 \mathrm{~cm}$ & Respon sangat cepat $(<1 \mathrm{~s})$ \\
\hline 3 & Ketiga & $60 \mathrm{~cm}$ & Respon cepat $(1 \mathrm{~s})$ \\
\hline 4 & Keempat & $80 \mathrm{~cm}$ & Respon cukup cepat $( \pm 1 \mathrm{~s})$ \\
\hline 5 & Kelima & $100 \mathrm{~cm}$ & Respon lambat $(>1 \mathrm{~s})$
\end{tabular}

Pada tabel 1. dapat dilihat bahwa sensor PIR sangat tergantung pada jarak antara sensor dan objek yang dideteksi, semakin jauh jaraknya semakin kurang efektivitas sensor tersebut. Untuk hasil percobaan tersebut masih bisa diterima karena jarak terjauh antara sensor dengan objek di dalam bilik paling jauh $100 \mathrm{~cm}$ berdasarkan ukuran bilik disinfektan tersebut. Kinerja sensor PIR dari sistem otomasi bilik disinfektan sangat baik seperti yang disajikan pada tabel 4.1. Pada percobaan yang kelima yaitu jarak maksimum antara objek dengan sensor PIR dalam bilik masih cukup cepat sehingga hasil kinerja sistem otomasi tersebut sangat bagus.
Pada penelitian ini dapat diketahui kebutuhan cairan disinfektan untuk setiap orang, sesuai dengan percobaan yang telah dilakukan dilakukan uji coba terhadap 10 orang. Untuk setiap orang dapat menghabiskan cairan disinfektan sebanyak $13 \mathrm{ml}$ selama 8 detik proses yang terjadi dalam bilik disinfektan. Untuk 10 orang dapat menghabiskan $130 \mathrm{ml}$ cairan disinfektan dari data tersebut dapat diketahui bahwa bilik disinfektan yang dirangcang ini cukup hemat karena dapat menyemprot sebanyak 800 orang untuk setiap satu kali pengisian cairan disinfektan. Bak penampungan cairan disinfektan yang digunakan memiliki kapasitas sebanyak 20 
liter. Hal ini sangat baik karena selain efektif untuk menekan virus corona yang sedang marak terjadi pada saat ini, hal ini juga dapat membantu untuk orang yang bekerja di luar rumah. Proses misting yang terjadi dalam bilik juga cukup baik karena akan langsung terkena ke seluruh tubuh orang yang berada dalam bilik tersebut.

\section{KESIMPULAN}

1. Sistem PIR pada dasarnya bekerja berdasarkan pada radiasi infra merah yang dipancarkan dari tubuh manusia. Cahaya infra merah (IR) merupakan radiasi elektromagnetik dengan panjang gelombang antara 0,7 dan 300 mikrometer. Manusia menjadi sumber radiasi inframerah. Ini ditemukan bahwa suhu tubuh manusia normal memancarkan IR pada panjang gelombang $10-12$ mikrometer. Sensor PIR juga tidak efektif digunakan di area terbuka yang langsung terkena sinar matahari.

2. Apabila sensor PIR membaca sinyal, maka sesor akan mengalirkan tegangan sebesar 5 Volt ke Arduino, kemuadian dibaca oleh Arduino sebagai sinyal digital berupa nilai logika 1 atau High. Kemudian Arduino memberikan perintah kepada relay, dimana relay tersebut adalah saklar bagi pompa yang akan memberi efek misting melalui nozle yang terpasang dalam bilik tersebut. Kinerja bilik disinfektan memiliki delay kurang lebih 1 detik saat mendeteksi orang yang masuk ke dalam bilik, kemudian setelah sistem berjalan proses penyemprotan akan berlangsung selama 8 detik, bilik hanya menampung 1 orang karena ukuran bilik yang hanya mampu menampung 1 orang saja. Otomasi lampu indikator tangki penampungan akan menyala jika bilik sudah digunakan sebanyak 800 kali semprotan, menandakan tangki tersebut perlu untuk diisi ulang.

\section{DAFTAR PUSTAKA}

AL-Kadi, T., AL-Tuwajiri, Z., \& AL-Omran, A. (2013). Arduino Wi-Fi Network Analyzer. Procedia Computer Science, XXI, 522-529.

Anonim. (1994). Environmental Protection Agency (EPA) Reregistration Eligibility Decision (RED) Chloroxylenol. Washington D.C.: United States Environmental Protection Agency (EPA).

Anonim. (2015). Webshaper/store. Dipetik April 04, 2020, dari

https://www.mybotic.com.my/webshaper/store/vie wProd.asp?pkProductItem=478 Anonim. (2016). Product Datasheet. India: Silicon Technolabs.

Anonim. (2020). datasheet. Dipetik April 2, 2020, dari

http://www.fecegypt.com/uploads/dataSheet/15223 36110_relay\%20module.pdf

Balogun, V., Oladapo, B., Adeoye, A. O., Kayode, J. F., \& Afolabi, S. O. (2018). Hysteresis Analysis of Thornton (IP6, IP12E, and TH5V) Magnetic Materials through The Use of Arduino Microcontroller. Journal of Material Research and Technology, 443-449.

Bayliss, C., \& Hardy, B. (2012). Transmission and Distribution Electrical Engineering (4th ed.). Kidlington, UK: Elsevier Ltd.

Brad, K. (2013, August). Getting Started with Arduino: A Beginner's Guide. Dipetik April 11, 2020, dari http://manuals.makeuseof.com.s3.amazonaws.com/ formobile/Arduino_-_MakeUseOf.com.pdf

Chodon, P., Adhikari, D. M., Nepal, G. C., Biswa, R., Gyeltshen, S., \& Chencho. (2013). Passive Infrared (PIR) Sensor Based Security System. (IJEECS) International Journal of Electrical, Electronics and Computer System, 1-5.

Corsi, C. (2012). Infrared: A Key Technology for Security System. Advances in Optical Technologies, 1-15.

dettol.co.id. (2020, August 14). products/cairanantiseptik. Diambil kembali dari dettol.co.id: 
https://www.dettol.co.id/products/cairanantiseptik/dettol-anti-bakteri-antiseptik-

cair/?utm_source=google\&utm_medium=CPC\&ut m_campaign=DAL\&utm_content $=$

AntiSeptik_bmm\&gclid=Cj0KCQjw7Nj5BRCZA

RIsABwxDKIVPfwrPvhyFJeJITg

m_Linvt3tUKPbPY4I3pY70PJRghdH9-

CbwLEaAm4

Fraden, J. (2004). Handbook of Modern Sensors Physics, Designs, and Applications (3rd ed.). New York: Springer-Verlag, Inc.

Gurevich, V. (2006). Electric Relays Principle and Applications. Haifa, Israel: Taylor \& Francis Group.

Junaidi, \& Prabowo, Y. D. (2018). Project Sistem Kendali Elektronik Berbasis Arduino.

Bandar Lampung: Aura.

Khairudin, M., Lanang, G., \& Arifin, A. (2020). Attadance System usiing Infrared Sensors. (hal. 16). Yogyakarta: IOP Publishing.

Kompas.com. (2020, March 28). Kompas.com. Diambil kembali dari Health:

https://health.kompas.com/read/2020/03/28/080000 468/panduan-bahan-dan-

keamanan-disinfektan-untuk-cegah-viruscorona?page $=$ all

Kumara, S. (2019). Investigation of Infrared Sensors for Robot Navigation. IOSR Journal of Engineering (IOSRJEN), 11-17.

Li, Z., Li, J., Li, X., Yang, Y., Xiao, J., \& Xu, B. (2020). Design of Office Intelligent Lighting System Based on Arduino. Procedia COmputer Science(166), 134-138.

Mcgrath, M., \& Scanaill, C. N. (2013). Sensing and Sensor Fundamentals. Dalam M. Mcgrath, \& C. N. Scanaill, Sensor Technologies Healthcare, Wellness and Environmental Applications (hal. 1550). Apress Open.

Narayana, S., Prasad, R. V., Rao, V. S., Prabhakar, T. V., Kowshik, S. S., \& Iyer, M. S.

(2015). PIR Snsor Characterization and a Novel Localization Technique using PIRs. 1-12.
Olsson, T., Gaetano, D., Odhner, J., \& Wiklund, S. (2008). Open Softwear: Fashionable Prototyping and Wearable Computing using The Arduino. Malmo, Swedia: Creative Common Attribution.

Saleh, M., \& Haryanti, M. (2017). Rancang Bangun Sistem Keamanan Rumah Menggunakan Relay. Jurnal Teknologi Elektro, Universitas Mercu Buana, VIII(3), 181-186.

Simeon, M., Elizabeth, A., Adoghe, A., Hope, O., \& Tita, S. W. (2018). Efficient Energy Management System using PIR Sensor. 2018 IEEE PES/IAS PowerAfrica (hal. 1-6). Ota, Nigeria: IEEE.

Smith, A. G. (2011). Introduction to Arduino: A Piece of Cake. Cary, North Carolina: CreateSpace Independent Publishing Platform.

Turang, D. A. (2015). Pengembangan Sistem Relay Pengendalian dan Pengamatan Pemakaian Lampu Berbasis Mobile. (hal. 75-80). Yogyakarta: UPN Veteran Yogyakarta.

Wati, M., Rahardja, F., \& Winsa, H. (2018). Perbandingan Aktivitas Antimikroba Isopropanol, Chloroxylenol, dan Triclosan terhadap Staphylococcus Aureus in Vitro. Rekayasa dan Teknologi, 1-10. 